\title{
STRATEGIC FRAMEWORK FOR SOCIAL ENTREPRENEURSHIP DEVELOPMENT IN BULGARIA
}

\author{
Venelin Terziev ${ }^{1}$ and Nikolay Nichev ${ }^{2}$ \\ ${ }^{1}$ Professor, Ph.D., D.Sc. (National Security), D.Sc. (Ec.), University of Rousse, Rousse, Bulgaria; \\ National Military University, Veliko Tarnovo, Bulgaria; University of Telecommunications and Post, \\ Sofia, Bulgaria, terziev@skmat.com \\ ${ }^{2}$ Colonel Associate Professor, Ph.D., National Military University, Veliko Tarnovo, Bulgaria, \\ nicheff@gmail.com
}

\begin{abstract}
Social economy and social entrepreneurship are subject to special attention from the European Commission (EC), particularly in recent years. This is due to their potential to find solutions to society's problems related to the creation of sustainable jobs, facilitating social and occupational integration, provision of social services and improving the quality of life, including the fight against poverty and social exclusion. Current paper makes analyses of the main strategic and policy documents supporting social entrepreneurship development in Bulgaria.
\end{abstract}

Keywords: Social enterprise, social economy, entrepreneurship

\section{INTRODUCTION}

Social enterprises and social entrepreneurship are central to the agenda of the European Commission, in particular in its strategy "Europe 2020" strategy for „smart, sustainable and inclusive growth”. They are a key element of the European social model and contribute to the implementation of socially significant goals of the strategy. Their growing importance - especially in the context of the economic and financial crisis is primarily the result of the need for Europeans from ethical and social dimension of their work, consumption, savings and investment ${ }^{1}$. In recent years, the European Commission began setting a policy framework for the social economy and social entrepreneurship, which found expression in a number of policy documents outlining the limits and opportunities for their development (Terziev \& Arabska, 2016e).

Among the specific objectives set by the Europe 2020 2010-2020 are providing 75\% employment for groups of 20-60 years, reducing school drop-out by $10 \%$ and providing at least 20 mil. less people who get in a situation of risk of poverty or social exclusion. Social entrepreneurship is recognized as a measure to

\footnotetext{
${ }^{1}$ Social enterprise and social entrepreneurship, Sofia, 2013. Economic and Social Council of the Republic of Bulgaria.
} 
achieve those objectives as ", tool to achieve sustainable development" ${ }^{\prime 2}$. The analysis of social policies shows that reducing direct support decreased and effectiveness, and sustainability of the "successful" models remains reciprocal of inputs. This trend can be stopped only by promoting innovative social models that overcome unemployment, poverty and social exclusion permanently. Social benefits and services, promoting education, training and skills in various fields, improving access to public services such as measures of influence should be complemented by targeted efforts and resources to maintain the forms of socially vulnerable groups would serve as a bridge to primary labor market. It successfully solution to achieve effective long-term results has recognized the role of social entrepreneurship.

Support and promotion of social enterprises can make the most of their growth potential and capacity to create social value added expressed through job creation, creative approaches to small business, new opportunities for social inclusion, and revenue for development activities of civic organizations ${ }^{3}$. The social economy plays no important role in the European Union, its contribution can be illustrated as follows: over 2 million operating social enterprises in member states of the European Union; employer of 11 million people, or nearly $6 \%$ of all employees; accelerated growth creating new social enterprises - 1 in 4 new companies are social enterprises.

The following formulation is stressed: Social enterprises covering a wide range of businesses with different legal forms that provide social services or goods to vulnerable or marginalized persons. These services include access to housing, healthcare, assistance for elderly or disabled persons, child care, access to employment and training as well as dependency management. Social undertakings also include undertakings that employ a method of production of goods or services with a social objective, but whose activities may be outside the sphere of provision of social goods or services. Those activities include social and professional integration by means of access to employment for people disadvantaged in particular by insufficient qualifications or social or professional problems leading to exclusion and marginalization.

\section{STRATEGIES AND POLICIES ENCOURAGING SOCIAL ENTREPRENEURSHIP}

In line with the strategy „Europe 2020” European Employment Strategy aims to create more and better jobs throughout the European Union (EU). In this respect the strategy by promoting measures to achieve three major objectives by 2020: 75\% employment rate among people aged between 20 and 64 years; the share of early school leavers below $10 \%$ and completion of higher education by at least $40 \%$ of people aged between 30 and 34 years; at least 20 million fewer poor or at risk of poverty and social exclusion of people.

The actions referred to in the flagship initiative "Agenda for new skills and jobs" are essential to achieving these goals. Each year, national governments (through the Employment Committee) and the European institutions prepare 'package of measures in the field of employment ${ }^{4}$.

The strategic objectives in support of the Commission's reply of unemployment and low levels of participation in the labor market in the EU with advanced and innovative policy ideas are: giving "new impetus to the combination of flexibility and security", involving all stakeholders in strengthening the elements of this combination and reinforce controls on national agreements combination of flexibility and security; selfemployment (Terziev \& Arabska, 2016d).

Despite the rapid development of the social economy sector in the European Union and the growing role of social enterprises to combat poverty and social exclusion, social entrepreneurship is almost imperceptible in Bulgaria (Tepavicharova et al., 2016). Although still modest in scale social enterprises in Bulgaria wear charge of changing attitudes towards so-called "welfare state" and allow for the mobilization of additional resources in the social sector through development of entrepreneurial potential and innovation ${ }^{5}$.

In implementation of Europe 2020, each member state adopted its own reform strategy that identifies key national objectives and actions to achieve them within the common European ones. According to the National Reform Programme Bulgaria 2020, part of the main areas of structural reforms concerning the modernization of services for access to the labor market, to social support, health care and education. It is envisaged that the implementation of active employment measures, including members of vulnerable groups through mechanisms to ensure sustainable employment, incentives for employers to find new jobs, programs for training, retraining and acquiring key skills and so on. There are four priority areas: better infrastructure; competitive Youth (reducing the share of early school leavers, increasing the number of young graduates,

\footnotetext{
${ }^{2}$ Encouragement and development of social enterprises in Bulgaria - Road map 2015-2020.

${ }^{3}$ Platform for social economy development in Bulgaria, Sofia, 2014.

${ }^{4}$ Research Report about the status and reinforcement of social entrepreneurship in Europe. National Report - Bulgaria.

Project SESBA: Social Enterprise Skills for Business Advisers, 2016.

${ }^{5}$ Platform for social economy development in Bulgaria, Sofia, 2014.
} 
encouraging young scientists realization of young people in Bulgaria); better business environment (higher employment, more investment, incl. R\&D innovation); greater confidence in state institutions (protection of interests of citizens and businesses, social justice and security). The program will try to achieve a higher standard of living for citizens in Bulgaria to $60 \%$ of the EU average by 2020 .

The measures that need to be implemented in the short term and which are related to the social economy are:

- Development of a new Law on Child;

- Merging rules in the field of social economy in a statutory instrument;

- Development of a National concept of active aging;

- Develop and implement a mechanism for determining the minimum wage, taking into account economic and social functions;

- Support for the provision of modern social housing for vulnerable, minority and socially disadvantaged groups and other disadvantaged groups.

In the medium term, the following measures:

- Assess the impact of policies and legislation related to material support to vulnerable groups;

- Investments in integrated services for early childhood development (for children from 0 to 7);

- De-institutionalization of child care (a network of social services in the community

- programs leaving specialized institutions, foster care, etc.);

- Support to families with children;

- Providing material support, appropriate forms of employment, training and retraining and accessible environment for people with disabilities;

- Development of social economy - creating new and support existing enterprises in the social economy;

- Increasing the adequacy of pensions;

- Creating a network of services for long-term care;

- Construction of social housing, including the most vulnerable members of the Roma community;

- Creating integrated social, health and educational services for homeless people;

- A study on homelessness, creating a statistical database on homelessness and its dimensions and develop a comprehensive strategy to combat homelessness.

It follows that the objectives of the National Programme are directly related to the social economy and improving the status of vulnerable groups in society ${ }^{6}$. Measures for development of social economy and the creation of new and support existing enterprises in the social economy on the development of social entrepreneurship in Bulgaria (Terziev \& Arabska, 2016a).

In 2011, the Bulgarian government adopted a policy document - "National concept of social economy”, which represent the vision and priorities for the promotion and development of the social economy in the country. This concept reflects the social commitment of the State to establish and strengthen an enabling environment for the implementation and development of models and practices in the field of social economy in Bulgaria. The social economy is perceived simultaneously as part of the real economy and civil society, in which individuals and/or legal persons, associations of volunteers or other organized entities doing business in the public interest and reinvest profits to achieve social goals (Terziev \& Arabska, 2016b).

National concept of social economy is an expression of social commitment of the State to establish and strengthen an enabling environment for the implementation and development of models and practices in the field of social economy in Bulgaria. It is an expression of intention and determination to promote awareness, culture and values related companies and organizations in the social economy. National Concept is a document by which presents vision and priorities to promote development of social economy in the country.

\footnotetext{
${ }^{6}$ Problemay sovremennoy ekonomiki: monografiya / M.M. Brutyan, M.P. Vahromeeva, T.M. Vorozheykina i dr. / Ed. S.S. Chernova. - Novosibirsk, 2016. Research report about the status and reinforcement of social entrepreneurship in Europe, pp. 183-260.
} 
Thus represents the active position of the state formed as a result of the joint efforts of a wide range of stakeholders. As a result of activity on the formation of a national position on the social economy through the National concept is expected to be developed and policies that lead to improved quality of life and well-being of vulnerable groups in society. It expected to be formed resistant sector to help overcome social exclusion of groups of people with disabilities. Expectations are for changes to the inclusion of a wide range of people in society who are in difficulty in access to jobs, services and resources (Terziev \& Arabska, 2016c).

National concept relies on understanding the social economy, reflected in the documents of the European Union and other international documents. It is in line with national strategic documents which are directly or indirectly related to the tasks arising from defined concept purposes. This document is a contribution to the objectives of Europe 2020 - strategy for smart, sustainable and inclusive growth that offers a vision of the social market economy of Europe for the 21st century. In light of the strategy that economic realities evolve faster than the political concept specifies ripe processes of the real economy, which should delineate the private sector development to become visible as a government policy context for raising living level people and the general public, which is committed to the social situation of marginalized groups in the labor market.

National concept provides proactive vision for future changes in legislation and practice of state authorities and vision for the integration of sectoral policies. It is a document for the development of which is attached approach based on the best national and international practices in this area, classified and analyzed under an interagency working group of experts with broad participation of representatives of state and international institutions, social partner organizations, NGOs.

State seeks to create a harmonious society by promoting the development of social economy in the country to achieve stability, economic growth and quality of life of people, especially of disadvantaged groups. Establishment of a favorable environment for the social economy sector is achieved through adequate policies and partnerships at international, national, regional and local level. All interested parties are actively involved in this process.

The vision of the concept is: validated developed social economy sector, through which extend the conditions for active inclusion of vulnerable groups of society is achieved flexibility and security in employment and developing territorial cohesion.

In the process of strengthening the model of social economy, the state plays an active role in promoting, encouraging and supporting the introduction of successful practices of social enterprises, including on the basis of voluntary activities developed within civil society. For the realization of these commitments his country creates an enabling legal and institutional environment and coordinated sectoral policies for accelerated introduction into practice of successful models of social enterprises. In so doing, the government will implement measures to increase productivity and competitiveness of these enterprises and will monitor the correct acquisition and adherence to brand "Product of the social enterprise."

A prerequisite in developing the concept is to reach a common agreement within the wide range of stakeholders on key issues related to the nature, scope, limits and potential of the social economy in the country to achieve better chances for social inclusion of disadvantaged groups; pooling resources to increase employment of social groups with limited access to services and resources or outside the labor market; Development of local and territorial cohesion.

The concept has the following specific objectives:

1. To serve as a reference for setting criteria for identification of enterprises and organizations of the social economy;

2. To serve as a current 'standard' in helping to support the development of social economy and stimulate artists and supporters to apply and disseminate the spirit of social solidarity;

3. To serve as a basis for creation of a favorable administrative and legal environment for the development of social economy enterprises (access to finance, social clauses in public contracts, tax breaks, etc.).

The development and promotion of sustainable social economy sector in the country will be achieved by implementing the guiding principles of good governance and the specific principles relating to the implementation of best practices and models of social enterprises. Specific principles on which the build best practices and models of social economy enterprises are related to ensuring unity between economic efficiency and the specific social objectives, developing activities in terms of public transparency and implement solidarity principles of internal management and decision-making.

State introduces the brand "A product of a social enterprise" in a logo and procedure for awarding entities, the results of which corresponds to the indicators set out in this Concept. The brand enjoys awarded 
enterprise to designate goods from its product specification, manufacturing and commercial space objects, documents, advertisements, clothing production and others. The purpose of the appropriation of the brand and its application is to attract public attention to the cause for which such businesses operate in order to attract the involvement of the mass consumer of consumer goods and services in the form of preferred purchases of preferred retail outlets.

The implementation of the concept of social economy will be implemented through a package of measures included in the annual implementation plans. The activities envisaged in the implementation of the measures are in line with the concept and are coordinated joint actions of stakeholders. Some of them are executed independently by public institutions and others - together with stakeholders from NGOs, social partners, employers' associations and others. The plan identifies the leading state institutions, defined in terms of their competence. Indicate deadlines for implementation of the activities and sources of funding. Plans are approved by the National Council for Tripartite Cooperation, then adopted by the Council of Ministers. The aim of the Action Plan on Social Economy for 2016-2017 is the development and promotion of the social economy and entrepreneurship ${ }^{7}$. The plan set out a number of awareness campaigns and forums to raise the visibility of social enterprises in Bulgaria and presentation of best practices in this field. The strategic document foresees the development of a methodology for assessing the social impact of social enterprises to raise living standards. Will introduce instruments for surveillance and monitoring of the contribution of social enterprises to improve the quality of life. It is planned to conduct annual European Forum on social enterprises. MLSP will continue to organize the annual national awards for social innovation.

In the Operational Programme „Human Resources Development” (2014-2020) the social economy and social entrepreneurship are displayed as a separate investment priority, thus further emphasizing the contribution of initiatives and measures that will increase opportunities for consolidating social sector economy.

Information exchange between the various levels is needed and should be implemented within the standard procedural requirements. In order to provide more visibility and awareness needs to be held information days and campaigns, and training to promote the ideas of social economy. Maintaining a forum to the site of concept can provide additional results in the distribution and adoption of the concept.

In connection with the development and improvement of the concept of the immediate tasks facing the government are: to execute the concept as institutionalize its implementation; to establish criteria for access to participation in the government's measures of enterprises and social economy organizations; propose legislative changes aimed at improving the favorable legal and administrative environment for social economy enterprises, taking into account the views of all stakeholders; to promote measures to enable statistical reporting of social economy.

Within the National Concept the social enterprise is defined as basic economic unit of the social economy, which stands between the private and public sectors. Activities carried out by social enterprises include: promoting employment opportunities and career development of people without jobs, people with disabilities and other vulnerable persons, as well as assistance in finding or returning to work; promoting opportunities for self-employment, entrepreneurship, start own business.

Objectives of the concept are to introduce criteria for identification of enterprises and organizations of the social economy and serve as a basis for creating a favorable (administrative and legal) environment for the development of social enterprises (access to financing social clauses in public contracts, tax breaks and etc.) (Terziev et al., 2016a).

Although the Bulgarian legislation there is no definition of social enterprise, and rules governing the status, form and operation of social enterprises in real life and practice there are many examples of functional social enterprises, which, on the one hand, pursue social objectives rather than other - apply economic mechanisms and market principles in its operations (Terziev et al., 2016b). Dynamic processes of social and economic development in recent years have clearly shown the following trends that reinforce the role and importance of the social economy in Bulgaria (Terziev et al., 2016c): inability of the state to deal with growing social needs of the population and growing population in need of support; debunked myth about the capabilities of the market economy to solve all social problems through the application of market principles; strengthen the role of local communities and civil society organizations in the process of development and provision of innovative social support services to the most vulnerable part of the population.

Reforms are needed and implementing innovative measures aimed to develop new approaches and models to tackle poverty and social exclusion (Terziev et al., 2016d). The social economy and entrepreneurship is

\footnotetext{
${ }^{7}$ Ministry of labour and social policy of the Republic of Bulgaria.
} 
one of the key instruments through which to complement ongoing government policy at the time of social support and smart and sustainable growth (Terziev et al., 2016e).

Absence of a comprehensive and systematic policy to promote the social economy, including the legal framework and financing, as well as specific sustainable measures for launching and supporting social enterprises and creating an environment conducive to the development of social economy (Terziev et al, 2016f).

Tracking the available practice of recent years in Bulgaria, it gives grounds to conclude that the entities operating in the social economy sector receive an incentive for development when there are national targeted program for their assistance, financing and development (Terziev et al., 2016h). Still lacks recognition of social enterprises as an innovative model for employment of disadvantaged groups in the labor market, as well as a new form for active social inclusion. It is important to define the areas and policies where the possibilities of social enterprises are still highly undervalued and unused (Terziev et al., 2016g).

\section{Combating Poverty and Social Exclusion}

According to the National Strategy for Combating Poverty and Social Exclusion 2020 the lack of employment is one of the main causes of poverty and social exclusion. The refore priority is promoting active inclusion of those furthest from the labor market - economically inactive young people, long-term unemployed, people on social assistance, with primary or lower education and no professional qualifications or lack of key competencies of people with permanent disabled people, elderly workers and others. Through the development of viable social enterprises can facilitate access to employment and to provide support for social inclusion of vulnerable groups by creating appropriate conditions for their professional integration in the social economy.

In addition, social enterprises can be a key tool for implementing the European strategy for employment, as combine measures for enhancing access to the labor market, supporting social services and the provision of adequate income and thus contribute to prevention of transmission of poverty between generations (Terziev et al, 2016i). Although it is important to provide services that help people to "enter" in the labor market is equally important that people with complex needs to integrate into society, even if it is difficult to provide them with employment opportunities. Despite the potential for poverty reduction and inclusion in the labor market of long-term unemployed and inactive persons, the social enterprises it is difficult to discern the level of policies and programs and thus remain undervalued and underutilized. Huge deficit in this area represents organizations that can provide integrated services necessary for social inclusion of people furthest from the labor market groups with an emphasis on social skills and improving individual social work with these individuals (Terziev et al., 2016j).

Employment Strategy of the Republic of Bulgaria 2012-2020 was developed in accordance with the National Reform Programme 2020 Employment Strategy aims to increase employment, productivity and social inclusion by improving the functioning of the labor market, increasing investment in human resources, supporting sustainable macroeconomic development. The strategy follows the priorities of the strategy „Europe 2020” strategy for smart, sustainable and inclusive economic growth. Employment policy should be developed and implemented with the help of organizations and institutions, it is necessary active cooperation with civil society organizations and NGOs. The aim is during 2015-2020 on to improve investment in human capital, and to ensure higher employment and a broad range of employable persons to be integrated in the market. It is important to be provided quality and efficient social services, community-based and family or family-like environment that has the potential for employment. Expressly stated that aims at development of social entrepreneurship and the creation of social enterprises - enterprises that aim to provide beneficial social effect against members of vulnerable groups to improve their living standards, employment, provision of services and / or other forms direct support. Social enterprises provide social services for vulnerable consumers, such as access to housing or care, assistance for elderly or disabled, outreach to vulnerable groups, child care, access to employment, education, dealing with addictions and others.

The priority of the National strategy to reduce poverty and promote social inclusion (2020) is to provide employment opportunities and increase income through active involvement of citizens in the labor market. The specific measures to be achieved include: increasing the employability of unemployed persons through the provision of training for acquisition of skills; providing employment for vulnerable groups in the labor market; provision of services necessary for the social inclusion of people furthest from the labor market groups with an emphasis on social skills and improving individual social work with these people; promoting entrepreneurship, including social entrepreneurship; providing conditions for reducing the number of working poor. 
Long-term strategy for employment of people with disabilities 2011-2020 adopted by the Council of Ministers, aims to provide disabled people of working age to effectively exercise their right to free choice of employment realization and to improve their quality of life to free and full inclusion in society of Bulgaria. They must create conditions for integration of disabled people into economic and social life. This will be achieved by people with disabilities providing them with the ability to access appropriate forms of vocational training and job development. Although social entrepreneurship is not mentioned in the text of the Strategy, it would be essential to achieving its objectives.

\section{Youth employment}

A major priority for the Commission is to combat youth unemployment, each EU member state has taken concrete political commitments implementing the European Youth Guarantee. The National Plan of Bulgaria foresees the implementation of measures to support job creation for hiring unemployed youths and subsidizing temporary employment for youth from regions where unemployment is high, while economic (public and private) infrastructure is poorly developed. Social enterprises can be supported by employers who hire young people for temporary work in Public Works, thereby acting as a tool for sustainable integration of young people into the labor market through a combination of temporary employment by providing incentives and training opportunities.

National Strategy for the youth 2010-2020 adopted by the Council of Ministers aims to create a suitable and favorable environment and conditions for school and university education as well as realization and active participation of young people in social and economic life. Strategic objective of improved economic activity and career development of young people. Part of this goal is the promotion of social entrepreneurship among young people. To achieve the objective need to promote and support public-private partnerships and social entrepreneurship in providing services for the development of young people.

Young people should not only be supported by social entrepreneurship, but also to understand more about its effect and importance.

\section{Equal access to participation in the economy of the population in small towns / rural areas}

Since over $70 \%$ of Bulgaria's territory falls in rural areas should be defined opportunities for the development of social enterprises in small towns. Traditionally, these regions are characterized by low quality and limited availability of public services, lack of social, educational and health services, as well as enhanced processes of depopulation and lack of employment opportunities and income. With these characteristics rural areas provide an excellent opportunity for social enterprises to offer innovative methods to fill existing market niches, while providing access to resources through local action groups and the implementation of the new instrument of the EC for community-led local development. In partnership agreement of the Republic of Bulgaria to the European Commission for the period 2014 - 2020, the outlining aid from European structural and investment funds clearly define the role of this development as a useful tool for the empowerment of local communities, including disadvantaged groups, improve the institutional capacity of local stakeholders and particularly NGOs and the creation of social innovation at the local level. In this context this development will promote the development of social economy and social enterprises in rural areas.

\section{Social innovation}

In connection with the social economy of particular interest are leading initiatives related to innovation, particularly in terms of contribution to social enterprises for social innovation; those related to the creation of new skills for new jobs and the European platform against poverty. The creation in 2013 of the European Union Programme for Employment and Social Innovation (EU Regulation 1296/2013 of the European Parliament) makes it possible to provide targeted funding of social enterprises that have an enormous capacity for social innovation and generate social capital.

\section{Integration of minorities}

Social enterprises are a key model for the effective implementation of the priority of creating employment for minorities, clearly outlined in the National Strategy for Roma integration by 2020 . Underestimated is the role of social enterprises to promote employment in green jobs by subsidizing jobs in environmental activities and the creation of quality employment and environmental protection. Another major opportunity to implement the model of social enterprises is to promote entrepreneurship, starting and managing their own businesses by Roma taking full advantage of the skills and traditions of the Roma in order to generate income.

Action Plan „Entrepreneurship 2020 - Bulgaria” was adopted by Protocol №46 of November 11, 2015 the Council of Ministers with a concrete 31 measures in accordance with the adopted by the Commission Action Plan „Entrepreneurship 2020 - Revival of the entrepreneurial spirit in Europe” (COM / 2012/0795 final). With the adoption of the Action Plan „Entrepreneurship 2020 Bulgaria” and proposed measures to 
implement the recommendations of the Commission by 2020, the country is committed in the long term conducted by the Ministry of Economy policy to promote and create new businesses. The measures of the Action Plan for Entrepreneurship 2020 - Bulgaria:

Field of action №1 - „Education and training in entrepreneurship to support growth and new business creation". This includes 15 measures. They are related to the introduction of programs for the formation of entrepreneurial skills in schools, updating entrepreneurship programs in vocational education, universities, secondary schools, promote entrepreneurship among young people, training of entrepreneurs in the field of agriculture and forestry etc.

Field of action №2 - „Better administrative and legislative environment for entrepreneurs and support the crucial stage of the life cycle". This includes 10 measures. They are connected with programs to fund startup entrepreneurs - young farmers in agriculture, support for pilot projects to develop new products through clusters in agriculture, support for start-up entrepreneurs students, support the growth of businesses by promoting the use of ICT and support through financial instruments. In this column included a measure to reduce the time needed to get licenses and permits.

Field of action №3 - „Strengthening the entrepreneurial culture in Europe for the growth of a new generation of entrepreneurs". This includes 6 measures. They are related to encouraging and promoting entrepreneurship in Bulgaria, developing a strategy to promote women's entrepreneurship, supporting a network of women entrepreneurs, support for the employment of people who care for children and other dependent family members, establishing a mechanism for exchange of experience and skills of older entrepreneurs to new entrepreneurs and promote entrepreneurship for unemployed young people under 29 years.

\section{CONCLUSION}

Social entrepreneurship is one of the most innovative ways to achieve a better quality of life, independence and inclusion in society of persons from vulnerable groups. There is a clear need key legislative changes to be taken in Bulgaria in order set in strategic and political national documents measures to become real mechanisms to support social entrepreneurship in Bulgaria, as well as the successful development of social enterprises, which also requires the creation of sustainable partnerships between business, NGOs and the public sector - partnerships in which each of these actors recognizes its role to achieve socially important objectives and is willing to invest resources in that

National policy for the development of social economy and social enterprises stand aloof from the common efforts to achieve the objectives of the National Strategy for reform. Although the National concept of social economy has been prepared as a strategic document with „anticipatory vision for future changes in legislation and practice of state authorities and vision for the integration of sectoral policies" still relevant sectoral policies are not clearly and consistently bound by it. This prevents creating a favorable legal and financial environment for the development of social enterprises.

\section{REFERENCE LIST}

Action Plan „Entrepreneurship 2020 - Bulgaria”.

Action Plan „Entrepreneurship 2020 - Revival of the entrepreneurial spirit in Europe” (COM / 2012/0795 final).

Agenda for new skills and jobs: http://ec.europa.eu/social/main.jsp?catld=1223/.

Employment Strategy of the Republic of Bulgaria 2012-2020.

Encouragement and development of social enterprises in Bulgaria - Road map 2015-2020.

Europe 2020 Strategy: http://ec.europa.eu/europe2020/index_en.htm/.

European Employment Strategy: http://ec.europa.eu/social/main.jsp?catld=101\&langld=en/.

European Union Programme for Employment and Social Innovation (EU Regulation 1296/2013 of the European Parliament).

Human Resources development Operational programme.

Long-term strategy for employment of people with disabilities 2011-2020. 
Ministry of labour and social policy of the Republic of Bulgaria: http://www.mlsp.government.bg/.

National concept of social economy, Sofia, 2011.

National Reform Program Bulgaria 2020.

National Strategy for Combating Poverty and Social Exclusion 2020.

National Strategy for Roma integration by 2020.

National Strategy for the youth 2010-2020.

National strategy to reduce poverty and promote social inclusion (2020).

Platform for social economy development in Bulgaria, Sofia, 2014:

http://pgf.osi.bg/data/file/Documents/Platform\%20Social\%20Economy\%20BG\%20MERI\%20EUROCIT IES.pdf/.

Problemay sovremennoy ekonomiki: monografiya / M.M. Brutyan, M.P. Vahromeeva, T.M. Vorozheykina i dr. / Ed. S.S. Chernova. - Novosibirsk, 2016. Research report about the status and reinforcement of social entrepreneurship in Europe, pp. 183-260.

Research Report about the status and reinforcement of social entrepreneurship in Europe. National ReportBulgaria. Project SESBA: Social Enterprise Skills for Business Advisers, 2016. Available at: http://sesbaproject.eu/en/research/.

Social enterprise and social entrepreneurship, Sofia, 2013. Economic and Social Council of the Republic of Bulgaria.

Tepavicharova, M., Bencheva, N., Terziev, V., Stoeva, T., \& Arabska, E. (2016). Social entrepreneurship encouragement in Bulgaria. International scientific conference "Contemporary challenges to the security in Europe" Proceedings, pp. 312-333.

Terziev, V.. \& Arabska, E. (2016a). Needs and challenges of social entrepreneurs. First SESBA Conference "Tips, skills \& tools for consulting social entrepreneurs", Agricultural University - Plovdiv, Project SESBA: Social Enterprise Skills for Business Advisers No 2015-1-EL01-KA202-014097 Erasmus+, pp. 51-60.

Terziev, V., \& Arabska, E. (2016b). Social entrepreneurship development in Bulgaria. In: The effectiveness of business management: investments and innovation. Collective monograph. - AMEET Sp. z o.o., Lodz, Poland, pp. 4-107.

Terziev, V., \& Arabska, E. (2016c). Social enterprises and social entrepreneurs. „Artillery, Aircraft Defense and CIS" Faculty, International Scientific Conference 2016 Collection of Papers, ISSN 2367-7902, pp. 409-416.

Terziev, V., \& Arabska, E. (2016d). Social entrepreneurship in Europe. „Vasil Levski” National Military University, "Artillery, Aircraft Defense and CIS" Faculty, International Scientific Conference 2016 Collection of Papers, pp. 401-408.

Terziev, V., \& Arabska, E. (2016e). Impact of social enterprises. Artillery, Aircraft Defense and CIS Faculty, International Scientific Conference 2016, Collection of Papers, pp. 391-400.

Terziev, V., Arabska, E., Dimitrovski, R., \& Pushova, L. (2016a). Challenges to social entrepreneurship development in Bulgaria. Eleventh international scientific conference Knowledge in practice, 16-18 December, 2016, Bansko, Bulgaria. Knowledge International journal - Scientific papers Vol. 15.1, pp. 517-525.

Terziev, V., Arabska, E., Dimitrovski, R., \& Pushova, L. (2016b). Conceptual and normative basis for developmnet of social entrepreneurship. Eleventh international scientific conference Knowledge in practice, 16-18 December, 2016, Bansko, Bulgaria. Knowledge International journal - Scientific papers Vol. 15.1, pp. 527-536.

Terziev, V., Bencheva, N. Arabska, E., Stoeva, T., Tepavicharova, M., \& Nichev, N. (2016c). Facts and figures on social enterprises in Bulgaria. Ninth International Scientific Conference THE TEACHER OF THE FUTURE, 17-19 June 2016, Albania. KNOWLEDGE International Journal Scientific Papers Vol. 13.1, pp. 183-188.

Terziev, V., Bencheva, N. Arabska, E., Stoeva, T., Tepavicharova, M., \& Nichev, N. (2016d). Social entrepreneurship in Bulgaria: barriers to growth. Ninth International Scientific Conference THE 
TEACHER OF THE FUTURE, 17-19 June 2016, Albania. KNOWLEDGE International Journal Scientific Papers Vol. 13.1, pp. 197-202.

Terziev, V., Bencheva, N. Arabska, E., Stoeva, T., Tepavicharova, M., \& Nichev, N. (2016e). Implications on social entrepreneurship development in Bulgaria. Ninth International Scientific Conference THE TEACHER OF THE FUTURE, 17-19 June 2016, Albania. KNOWLEDGE International Journal Scientific Papers Vol. 13.1, pp. 203-208.

Terziev, V., Bencheva, N., \& Arabska, E. (2016f). Implications on development of social economy in Bulgaria. Scientific Journal "Economics and Finance", pp. 55-63.

Terziev, V., Bencheva, N., Arabska, E., \& Stoeva, T. (2016g). Innovations in the public policies in Bulgaria. Yearbook of Bishop Konstantin Preslavski University of Shumen, Vol. XXD, pp. 132-152.

Terziev, V., Bencheva, N., Arabska, E., \& Stoeva, T. (2016h). Insight into the social entrepreneurship in Bulgaria. Yearbook of Bishop Konstantin Preslavski University of Shumen, Vol. XXD, pp. 153-160.

Terziev, V., Bencheva, N., Stoeva, T., \& Arabska, E. (2016i). Social enterprises in Bulgaria. Scientific Journal "Economics and Finance", pp. 6374.

Terziev, V., Bencheva, N., Tepavicharova, M., \& Arabska, E. (2016j). Encouragement of social entrepreneurship in Bulgaria. Scientific Journal "Economics and Finance", pp. 45-55. 